\title{
Correlation Analysis of the Halal Certification Process and Perceptions of the Cost of Halal Certification with the Intentions of Food and Beverage SMEs Actors
}

\author{
Sugeng Santoso ${ }^{1^{*}}$, Selma Alfarisah ${ }^{2}$, Ari Ana Fatmawati ${ }^{3}$, Rian Ubaidillah ${ }^{4}$
}

\author{
1 Mercu Buana University, Indonesia; sugeng.santoso@mercubuana.ac.id \\ 2 Mercu Buana University, Indonesia; alfarisahselma@gmail.com \\ Mercu Buana University, Indonesia; ariana.aa66@gmail.com \\ Mercu Buana University, Indonesia; rianubaidillah@gmail.com \\ * Correspondence: sugeng.santoso@mercubuana.ac.id
}

Received: 2021-02-12; Accepted: 2021-06-23; Published: 2021-08-31

\begin{abstract}
As one of the countries with the largest Muslim population in the world (87.18\%), Indonesia has the potential to become the center of the world's halal industry. Halal certification can increase the competitiveness of MSME products, especially related to product guarantees to provide comfort, security, safety, and certainty of the availability of halal products for the public in consuming and using the product. The purpose of this study is to analyze the problems and solutions for food and beverage SMEs (Ekraf) related to the Halal Certification Process and Perceptions of Halal Certification Costs with the Actor's Intention to obtain a halal certificate. The research method uses qualitative and quantitative approaches by using primary and secondary data. The qualitative approach was carried out through FGD, webinars and participant observation with key informants and supporting informants. The quantitative approach is carried out by distributing questionnaires to 100 business actors and then processing the Pearson Product Moment correlation data. The results of the study show (i) the halal certification process (by assisting) has a very strong correlation with the perpetrator's intention and is significant, (ii) the perception of the cost of halal certification (with the cost of halal certification that gets subsidized) has a strong correlation with the perpetrator's intention and is significant, ( iii) The Halal Certification Process has a strong correlation with the perpetrators' perceived Halal Certification Costs and is significant, (iv) The Halal certification process and the perceived cost of Halal certification with the perpetrator's intention are very strong and significant. The halal certification process and the perception of the cost of halal certification, both individually and jointly, are correlated with the intentions of food and beverage creative economy actors (MSMEs). In order to achieve this goal, the synergy between central and regional stakeholders and related parties is needed.
\end{abstract}

Keywords: Food and Beverage SMEs; Halal Certificate; Process and Cost of Halal Certification; Qualitative and quantitative approaches.

Abstrak: Indonesia sebagai salah satu negara dengan penduduk muslim terbesar di dunia $(87,18 \%)$ berpotensi menjadi pusat industri halal dunia. Melalui Sertifikasi Halal dapat meningkatkan Daya Saing Produk UMKM khususnya terkait dengan penjaminan produk untuk memberikan kenyamanan, keamanan, keselamatan, dan kepastian ketersediaan produk halal bagi masyarakat dalam mengonsumsi dan menggunakan produk. Tujuan dari penelitian ini adalah menganalisis permasalahan dan solusi terhadap pelaku UMKM (Ekraf) makanan dan minuman terkait Proses Sertifikasi Halal dan Persepsi Biaya Sertifikasi Halal dengan Intensi Pelaku untuk memperoleh sertifikat halal. Metode penelitian menggunakan pendekatan kualitatif dan kuantitatif dengan menggunakan data primer dan sekunder. Pendekatan kualitatif dilakukan dengan melalui FGD, webinar dan observasi partisipan dengan informan kunci dan informan pendukung. Pendekatan kuantitatif dilakukan melalui penyebaran kuesioner kepada 100 pelaku usaha kemudian dilakukan pengolahan data dengan korelasi Pearson Product Moment. Hasil penelitian menunjukkan (i) Proses sertifikasi halal (dengan melakukan pendampingan) memiliki korelasi sangat kuat dengan intensi 
pelaku dan signifikan, (ii) Persepsi Biaya Sertifikasi Halal (dengan Biaya sertifikasi halal yang mendapat subsidi) memiliki korelasi kuat dengan intensi pelaku dan signifikan, (iii) Proses Sertfikasi Halal memiliki korelasi kuat dengan Persepsi Biaya Sertifikasi Halal pelaku dan signifikan, (iv) Proses sertifikasi halal dan persepsi biaya sertifikasi halal dengan intensi pelaku menunjukkan sangat kuat dan signifikan. Proses sertifikasi halal dan persepsi biaya sertifikasi halal baik secara sendiri maupun secara bersama-sama berkorelasi terhadap intensi pelaku ekonomi kreatif (UMKM) makanan minuman, agar tujuan tercapai maka diperlukan sinergi stakeholder tingkat pusat maupun daerah serta pihak terkait.

Kata Kunci: Pendekatan kualitatif dan kuantitatif; Proses dan Biaya Sertifikasi Halal; Sertifikat Halal; UKM Makanan dan Minuman.

\section{Introduction}

Currently, the development of the sharia economy globally has increased rapidly, especially in non-Muslim countries. According to Pew Research Center (2017), in 2020 Muslim population is 1.9 billion or about $24.9 \%$ of the total world population, which is expected to continue to increase by $73 \%$ in 2050. As a country with a majority Muslim population, Indonesia has the potential to become the largest halal economic center in the world, especially the center for the development of the world's halal industry, namely in the Asia Pacific region, which controls almost $62 \%$, namely products that cover the needs of Muslims (Kemenparekraf/ Baparekraf RI, 2020). It is necessary to accelerate the increase in added value from product innovations produced more uniquely and of high quality (Dumilah, Komarudin, Ubaidillah, Siagian, \& Santoso, 2021). One of the essential things for Muslim consumers is the halalness of a product. Basically, the principles of Muslim-friendly tourism are the same as the CHSE principles, namely implementing cleanliness, health, safety and the environment. The CHSE principle is not only applied at tourist sites but also to all facilities, including food and beverages that are traded (Santoso, Natanael, et al., 2021).

The halal food industry is essential for Muslims worldwide as it serves to ensure that the food they consume daily meets Shariah requirements (Hasri, Taib, \& Ahmad, 2016). Halal certificate is one of the tools used to label halal products that are valid according to Islamic law, free from prohibited materials and processes. Halal certificate is the right of Muslim consumers who must receive protection from the state (Syafrida, 2016). With a halal certificate, the food and beverages available in Indonesia are guaranteed to be halal for tourists. So that Muslim consumers will feel safe and comfortable consuming these products (Santoso, Natanael, et al., 2021). Because community assesses by paying attention to applicable health protocols (Santoso, Hapsari, Difoasih, \& Prianto, 2021). In addition, the halal certificate also provides a label to non-Muslims that food and beverage products have been tested using good ingredients and are safe for consumption.

In Indonesia, halal certificates were initially voluntary, but after the enactment of Law no. 33 of 2014 concerning Halal Product Assurance (UUJPH) dated October 17, 2014, which states that after 5 years of promulgation, to be precise on October 17, 2019, halal certificates are mandatory. The entire halal certification process scheme is through the (Halal Product Assurance Organizing Agency) BPJPH (Kemenparekraf/ Baparekraf RI, 2020). The consequence of this regulation is that consumers will get comfort, security, safety, and certainty of the availability of halal products for the public (consumers) in consuming and using a product. This halal guarantee regulation can increase business actors' added value in producing or selling Halal Products (Santoso, Natanael, et al., 2021). In the midst of the covid 19 pandemics, certification is very important, this is because of the lack of intensity between producers and consumers. Therefore, consumers need guarantees for their food, especially with the existence of services. Implementation of delivery service applications that have a positive impact on business actors and the economy does not only in the form of economics, but also in the form of relations (Adhiguna, Mahdi, Fauzan, Rabbani, \& Santoso, 2021). The halalness of a product includes the halal logo and the supply chain in carrying out its business processes. To ensure that MSME products can compete in the 
Global Halal Market, standardization and control over product quality assurance is needed in the form of Halal Certification (Qomaro, Hammam, \& Nasik, 2019).

Currently, BPJPH emphasizes the start of halal certification for food and beverages because this is a basic need of the community. Starting October 17, 2019, food and beverages have started the mandatory period of halal certification (Sukoso, 2020). However, the long process and the high costs incurred are obstacles for some business actors to obtain halal certification. It can be seen from the research conducted by Prabowo (Prabowo, Abd Rahman, Ab Rahman, \& Samah, 2015), which states that there are factors that hinder business actors from obtaining halal certification, namely costs, certification procedures, and government role. Akim (2019) also stated that the halal certification process is one of the main problems for business actors. This research is expected to be input for the government in carrying out programs or activities in halal certification.

Food and beverage (culinary) are one of the sub-sectors of the creative economy, which is the Ministry of Tourism and Creative Economy domain. The creative economy has characteristics related to value chains and added values that contain intellectual property. In addition, the role of the central and local governments must be increased because the authorities' responsibility is to develop a conducive innovation-based ecosystem (Santoso, 2020). The Ministry of Cooperatives and SMEs, through the Deputy for Production and Marketing on July 28, 2021, at the Webinar Know the Concept and Halal certification, stated that currently, only medium and large businesses could finance their halal certification. The certification fee ranges from Rp. 2.5 million to Rp. 5 million per product type). A breakthrough in the relaxation of certification licensing is needed to provide solutions for developing Halal Product Assurance (JPH) at the MSE level. Halal certification for MSEs is included in discussing the Ease and Protection of MSMEs cluster and ease of doing business in the Omnibus Law (2020). The conventional culinary sub-sector requires rearranging business processes in the process of raw materials, packaging, and product certification (Santoso, Natanael, et al., 2021).

The purpose of this study is to analyze the problems and solutions for food and beverage SMEs (Ekraf) actors related to the Halal Certification Process and Perceptions of Halal Certification Costs with the Actor's Intention to obtain a halal certificate. The research method used is a qualitative and quantitative approach. The combination of quantitative and qualitative analysis ensures that the data obtained are comprehensive, valid, reliable, and objective. In making these decisions, we not only look at the point of view of data-based decision-makers, but we can make decisions. Observation and interviews to see the problem more deeply.

The qualitative approach was carried out through FGDs and participant observation. Observations are made by analyzing the basics used as the basis for decision making, starting from the user side, the market, to the relationship between the two. The key informants who became the object of observation were the Head of BPJPH, the Director of KNEKS, Officials from the Ministry of Tourism and Creative Economic, the Ministry of Cooperatives and SMEs, and the Coordinating Ministry Maritime Affairs and Investment. Meanwhile, the supporting informants are Creative Economy Actors (MSMEs).

A quantitative approach through descriptive analysis is used to analyze the data by describing the data that has been collected to obtain a picture based on actual observations by describing 100 respondents' responses by distributing questionnaires. The population of this study is food and beverage SMEs (Ekraf) actors. SPSS data processing is used to test the characteristics of respondents and descriptive analysis in this study. Several tests/analytical tools used are: validity test is used to measure the validity of a questionnaire, reliability test is to determine the consistency of an instrument, correlation is used to determine the relationship between the variables studied, significance test, multiple correlations. The number of samples in this study was 100 respondents spread online and offline.

The research variables in this article were obtained from the development of a literature study in previous research, which stated that there were inhibiting factors for business actors to obtain halal certification, one of which was the cost of halal certification (Fauzan, 2020). This requires support from various parties in terms of equipment and facilities as well as financial incentives to facilitate business actors In meeting the requirements of halal certification. In addition, this variable was also developed 
through a series of observations at the webinar on July 28, 2020, on Knowing the Concept and Halal Certification of MSME Products and then through two FGDs attended by the Head of BPJPH as a resource person. The webinar results state that one of the challenges for business actors to obtain a halal certificate is the length of the administrative process and the high total cost for registration, audit, and fatwa.

The variables in this study are (1) Halal Certification Process, namely the process or stages of halal certification to obtain halal certification, namely through an application, examination, determination, testing, checking, fatwa, and issuance. At this stage of the process, BPJPH has the authority to apply for and issue halal certification. MUI has the authority to conduct scientific studies and hear halal fatwas. Meanwhile, LPH has the authority to inspect and test the halalness of a product; (2) Perception of Halal Certification Costs Perceived cost of halal certification is information that individuals absorb, namely the costs that must be incurred by business actors to apply for or obtain halal certification; (3) The creative economy actor's intention is the creative economy actor's intention/desire to implement halal certification in order to increase product competitiveness to increase product value.

\section{Research methods}

The research method with a quantitative approach is described in accordance with Figure 1, where there are 4 relationships, namely R1, R2, R3 and R4.

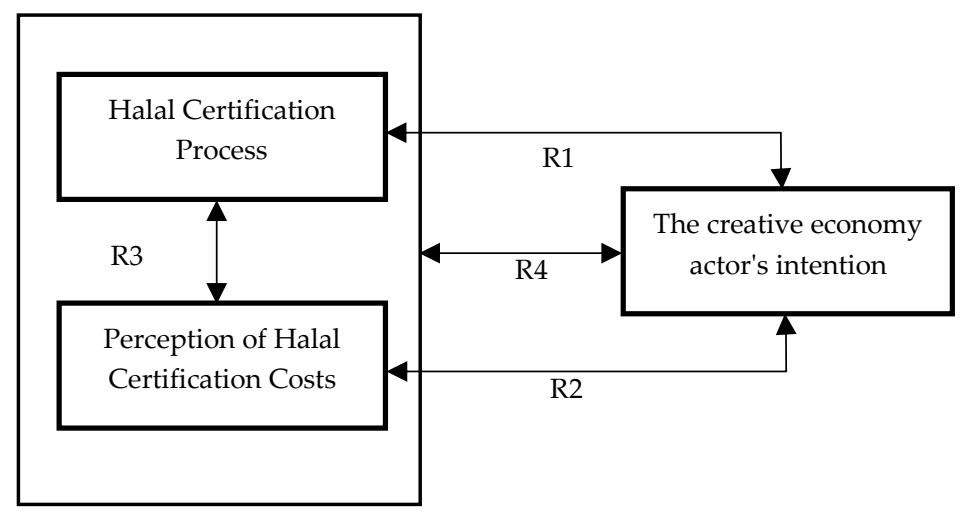

Figure 1. Research methods

Table 1 describes the Research Variables, Indicators, Approach \& Variable Measurement Scale and Data Source. In the research approach, there is information that quantitative and qualitative approaches are carried out.

Table 1 Research Variables, Indicators, Approach \& Variable Measurement Scale

\begin{tabular}{|c|c|c|c|}
\hline Variabel & Indicator & $\begin{array}{l}\text { Approach \& Variable } \\
\text { Measurement Scale }\end{array}$ & Data source \\
\hline \multirow[t]{2}{*}{$\begin{array}{l}\text { Halal } \\
\text { Certification } \\
\text { Process }\end{array}$} & $\begin{array}{l}\text { - Assistance is required in } \\
\text { undergoing the certification } \\
\text { process }\end{array}$ & Qualitative - FGD & $\begin{array}{l}\text { BPJPH, Ministry of } \\
\text { Cooperatives \& } \\
\text { SME, KNEKS, } \\
\text { Ministry of Tourism } \\
\text { \& Creative Economy }\end{array}$ \\
\hline & & Quantitative -Interval & Questionnaire \\
\hline $\begin{array}{l}\text { Perception of } \\
\text { Halal } \\
\text { Certification } \\
\text { Costs }\end{array}$ & $\begin{array}{l}\text { - The cost of halal certification is } \\
\text { subsidized for MSMEs }\end{array}$ & Qualitative - FGD & $\begin{array}{c}\text { BPJPH, KNEKS } \\
\text { Ministry of Finance } \\
\text { Ministry of Tourism } \\
\text { \& Creative Economy } \\
\text { and Related } \\
\text { Ministries }\end{array}$ \\
\hline
\end{tabular}




\begin{tabular}{|c|c|c|c|}
\hline & & Quantitative -Interval & Questionnaire \\
\hline $\begin{array}{l}\text { The intention of } \\
\text { Creative } \\
\text { Economy Actors } \\
\text { (MSMEs) }\end{array}$ & $\begin{array}{l}\text { - Halal certificates add product } \\
\text { selling value, provide product } \\
\text { trust and safety }\end{array}$ & Quantitative -Interval & Questionnaire \\
\hline
\end{tabular}

Source: Results of Data Processing (Modification), 2021

\section{Result and Discussion}

Based on the results of validation testing on the results of the questionnaire of 100 respondents both offline and online, the $r$-count of the halal certification process variable $=0.95$, the variable perception of halal certification costs $=0.85$ and the actor's intention variable is 0.79 ; all three are greater than $\mathrm{r}$ table $=0.1966$, then the questionnaire instrument is valid.

Table 2 Reliability Test

\begin{tabular}{lllll}
\hline No. & Variable & $r_{\text {Alpha }}$ & $r_{\text {kritis }}$ & Criteria \\
\hline 1. & Halal Certification Process & 0.936 & 0.600 & Reliable \\
2. & Perception of Halal Certification Costs & 0.934 & 0.600 & Reliable \\
3. & The intention of Creative & 0.806 & 0.600 & Reliable \\
& Economy Actors (MSMEs) & & & \\
\hline
\end{tabular}

Source: Data Processing Results

Based on Table 2 above, the reliability test was carried out on the question items that were declared valid. A variable is said to be reliable or reliable if the answers to the questions are always consistent and the three instruments are declared reliable.

Table 3 Calculation Results of R1 Pearson Product Moment Correlation between Halal Certification Process and Intentions of Creative Economy Actors (MSMEs)

\begin{tabular}{|c|c|c|c|}
\hline \multicolumn{4}{|c|}{ Correlations } \\
\hline & & $\begin{array}{c}\text { Halal } \\
\text { Certification } \\
\text { Process }\end{array}$ & $\begin{array}{l}\text { Intention of } \\
\text { Creative } \\
\text { Economy } \\
\text { Actors } \\
\text { (MSMEs) }\end{array}$ \\
\hline \multirow{3}{*}{$\begin{array}{l}\text { Halal Certification } \\
\text { Process }\end{array}$} & Pearson Correlation & 1 & $.801^{*}$ \\
\hline & Sig. (2-tailed) & & .000 \\
\hline & $\mathrm{N}$ & 100 & 100 \\
\hline \multirow{3}{*}{$\begin{array}{l}\text { Intention of Creative } \\
\text { Economy Actors } \\
\text { (MSMEs) }\end{array}$} & Pearson Correlation & $.801^{* *}$ & 1 \\
\hline & Sig. (2-tailed) & .000 & \\
\hline & $\mathrm{N}$ & 100 & 100 \\
\hline
\end{tabular}

Result. Based on Table 3 above, The Pearson correlation R1 calculation results show that the halal certification process (by assisting) strongly correlates with the intentions of creative economy actors (MSMEs) of 0.801 . The R1 correlation between the halal certification process and the intention of creative economy actors (MSMEs) is significant.

Discussion. Based on the results of the questionnaire, it was found that most of the respondents did not understand the halal certification process so that they needed assistance in undergoing the certification process because the certification process was considered complicated and complex. 
Meanwhile, from the FGD and participant observations results, it was explained that the fulfilment of the requirements for MSMEs (Ekraf actors) that were certified halal needed to receive training and assistance. The halal certification process was accelerated from 93 working days after BPJPH conducted a comparative study with Malaysia, which only took 20 working days to issue halal certification, and this was also done based on inputs and complaints received by business actors. Officially, the halal certification process has been accelerated in the Job Creation Law, namely, (1) The verification period for the halal certificate application is carried out no later than one working day. (2) The determination of the LPH is carried out within a maximum period of one working day as of the application document. (3) Inspection and/or testing of product halalness is carried out by the Halal Inspector no later than fifteen working days. (4) decide on the halalness of a Product no later than three working days after MUI receives the results of the inspection and/or product testing from LPH. (5) issued by BPJPH no later than one working day after the issuance of the product halal fatwa. So it is calculated that the halal certification process is accelerated from 93 working days to 21 working days.

An important aspect in analyzing the enforcement of halal certification for halal food and beverages in Indonesia is the acceleration of halal certification. The certification in question is to carry out a series of examinations carried out by auditors competent in their fields to determine the halal status and then create a written fatwa stating the halalness of products on halal certification (Faridah, 2019). Fatmawati and Santoso (2020) revealed that it was proposed to accelerate halal certification from the food and beverage sector and change the healthy and halal food brand. In addition, small business actors can also declare themselves if the process and materials are following the policies contained in the BPJPH. This is known to be done to make it easier for small business actors to be able to establish halal certification obligations. Furthermore, now BPJPH has designed an application system, namely the Halal Assurance System (JPH), that can be accessed by business actors. This is the answer to the problems faced by business actors by Talib (2017). The lack of awareness about the halal certification process and the complexity of the process is an obstacle for many small and micro industries. The halal certification has not been a priority, so it is not included in calculating Indonesian halal food production.

Several conditions open up opportunities for the halal food industry to become a significant market force. Elasrag (2016) argues that the significant increase in the Muslim population and the purchasing power of Muslims will bring many opportunities in the global halal industry. Another condition is the increasing awareness of Muslims to consume halal food. In addition, the trend of consumption of halal food by non-Muslim consumers is increasing due to ethical and safety reasons. Several countries globally, both Muslim and non-Muslim, have taken great opportunities for the halal market. Muslim countries compete with each other to become halal hubs.

Malaysia, Indonesia and Pakistan aspire to become halal hubs and are working aggressively to become key producers of halal food (Mohamad \& Backhouse, 2014). Then Turkey promoted itself as a halal gateway to Europe and had its halal standards and certifications. Halal product certification has positive implications in building a halal business climate in Indonesia. Halal certification provides protection, guarantees, halal product information and becomes an instrument of business ethics for consumers. Halal certification benefits consumer confidence and reaches the global halal food market (Warto \& Samsuri, 2020). And this requires counselling and assistance so that MSME actors can survive in any condition (Alika, Santoso, Nurmaliki, \& Anisa, 2021). The same thing was conveyed by Redata et al. (2021). The assistance provided by the business community for MSME actors to improve the quality of their production to meet customer satisfaction. 


\section{Perception of Halal Certification Costs}

Table 4 Calculation Results of R2 Pearson Product Moment Correlation between Perceived Halal Certification Costs and Intentions of Creative Economy Actors (MSMEs)

\begin{tabular}{|c|c|c|c|}
\hline \multicolumn{4}{|c|}{ Correlations } \\
\hline & & $\begin{array}{l}\text { Perception of } \\
\text { Halal } \\
\text { Certification } \\
\text { Costs }\end{array}$ & $\begin{array}{l}\text { Intention of } \\
\text { Creative } \\
\text { Economy } \\
\text { Actors } \\
\text { (MSMEs) }\end{array}$ \\
\hline \multirow{3}{*}{$\begin{array}{l}\text { Perception of Halal } \\
\text { Certification Costs }\end{array}$} & Pearson Correlation & 1 & $.755^{* *}$ \\
\hline & Sig. (2-tailed) & & .000 \\
\hline & $\mathrm{N}$ & 100 & 100 \\
\hline \multirow{3}{*}{$\begin{array}{l}\text { Intention of Creative } \\
\text { Economy Actors } \\
\text { (MSMEs) }\end{array}$} & Pearson Correlation & $.755^{* *}$ & 1 \\
\hline & Sig. (2-tailed) & .000 & \\
\hline & $\mathrm{N}$ & 100 & 100 \\
\hline
\end{tabular}

Source: Data Processing Results

Result. Based on Table 4 above, The Pearson correlation R2 calculation results show that the perceived cost of halal certification (with the cost of halal certification receiving subsidies) strongly correlates with the intention of creative economy actors (MSMEs) of 0.755 . The correlation between Perceived Halal Certification Costs and the intention of creative economy actors (MSMEs) is significant.

Discussion. From the FGD, it is known that the certification cost is expensive by MSMEs, so it is felt that it needs to be facilitated. For micro and small business actors, the cost of halal certification can be facilitated by other parties. Currently, BPJPH and the Ministry of Finance have collaborated with relevant agencies and institutions to provide facilitation in the form of financial assistance by the central government through the APBN, state revenues and expenditures. Through regional revenue and expenditure budgets, local governments, companies, social institutions, religious institutions, and associations. Alternatively, the community organize a particular budget to help make it easier for small business actors to obtain halal certificates through subsidies facilitated by the government and related institutions for micro and small business actors.

The explanation of Table 5 is as follows: The MSME development strategy (creative economy) carried out by MSMEs (Ekraf) requires synergy between MSME actors, improving the quality of products and services as well as full support from the government, the private sector in increasing capital (Tadjuddin \& Mayasari, 2019). However, for business actors belonging to the upper-middle class, there are cost components that must be incurred in the halal certification process, namely for registration, fatwa trial and $\mathrm{LPH}$ with details of costs including:

1. Registration fee: $200,000-500,000$

2. Certification fee: 1,5 million-5 million (excluding LPH costs)

3. LPH costs: BPJPH stipulates the upper and lower limits, with the following criteria: number of auditors, length of day on-site inspection, accommodation and transport. This is explained in Table 5.

The Head of the Halal Product Assurance Agency (BPJPH) of the Ministry of Religion explained the changes that occurred after the UUJPH was ratified regarding the halal certification obligations, costs, and obstacles in implementing halal certification in Indonesia as follows: and also producers, namely explicit protection to obtain rights and obligations and others, especially for producers, the law provides legal protection to business actors and consumers with their rights. Producers produce halal products with halal standards; consumers get or buy them, it is essential. It is emphasized that producers get legal certainty. When there is legal certainty, those producers will concentrate on 
competency issues and quality improvement rather than dealing with wandering problems. Consumers feel comfortable because, with certification, it is obvious. Later in Indonesia, restaurants with a halal certificate must put a halal logo or label on the outside and be easily recognizable and can be checked with a smartphone.

Table 5 Conditions for halal certification in Indonesia

\begin{tabular}{lll}
\hline Component & Existing Condition & Recommendation \\
\hline Certification fee & $\begin{array}{l}\text { UMK is charged a certification } \\
\text { fee of Rp. 2.500.000,- s.d Rp. } \\
3.400 .000,-\end{array}$ & Subsidies \\
\hline Certification time & $\begin{array}{l}9 \text { days for domestic and 117 } \\
\text { days for foreign products }\end{array}$ & $\begin{array}{l}\text { The time for the inspection } \\
\text { process by LPH is a maximum } \\
\text { of 21 days }\end{array}$ \\
\hline Requirements & All efforts are carried out by the & $\begin{array}{l}\text { Especially for micro-business } \\
\text { with products that have a low- } \\
\text { risk level and without risk, halal } \\
\text { certification is obtained through } \\
\text { a single self-declaration }\end{array}$ \\
\hline
\end{tabular}

Source: SK LPPOM MUI no: PDM.11-01 April 3, 2017, Halal Certification Guidelines

If a business actor has obtained halal certification, the product is undoubtedly halal, while consumers will benefit from consuming a product. A halal certificate is one of the essential things for Muslim consumers because, with a halal certificate, consumers feel safe and comfortable consuming a product. Halal certification acknowledges the halalness of a product issued by the Halal Product Guarantee Agency (BPJPH) based on a written fatwa issued by the Indonesian Ulema Council (Agus, 2017).

\section{Halal Certification Process with Perceived Halal Certification Costs}

Table 6 Calculation Results of R3 Pearson Product Moment Correlation between Halal Certification Process and Perception of Halal Certification Costs

\begin{tabular}{llrrr}
\hline & \multicolumn{1}{c}{ Correlations } & & \\
\hline & & $\begin{array}{c}\text { Halal } \\
\text { Certification } \\
\text { Process }\end{array}$ & $\begin{array}{c}\text { Perception of } \\
\text { Halal } \\
\text { Certification } \\
\text { Costs }\end{array}$ \\
\hline Halal Certification Process & Pearson Correlation & 1 & $.719^{* *}$ \\
\cline { 2 - 5 } & Sig. (2-tailed) & 100 & .000 \\
\cline { 2 - 5 } & $\mathrm{N}$ & $.719^{* *}$ & 100 \\
\hline Perception of Halal & Pearson Correlation & .000 & 100 \\
\cline { 2 - 5 } Certification Costs & Sig. (2-tailed) & 100 & 100 \\
\cline { 2 - 5 } & $\mathrm{N}$ & & \\
\hline$* *$ Correlation is significant at the 0.01 level (2-tailed). & & \\
\hline
\end{tabular}

Source: Results of data processing

Result. Based on Table 6, the Pearson correlation R3 calculation results show that the Halal Certification Process strongly correlates with the Perceived Cost of Halal Certification for Creative Economic Actors (MSMEs) of 0.719. The correlation between the Halal Certification Process and Perceived Halal Certification Costs is significant. 
Discussion. There is an MoU to raise assistance for Micro, Small, and Medium Enterprises (MSMEs) to rise. MSE actors are assisted with halal certification fees in collaboration with relevant agencies and approved in the MoU agreement. We need communication and synchronization to have harmony and commitment from related parties in implementing halal certification.

Halal Certification Process and Perception of Halal Certification Costs with Intentions of Creative Economy Actors (MSMEs)

Table 7 Results of R4 Calculation of Pearson Product Moment Correlation between Halal Certification Process and Perception of Halal Certification Costs with Intentions of Creative Economy Actors (MSMEs)

\begin{tabular}{|c|c|c|c|c|}
\hline \multicolumn{5}{|c|}{ Correlations } \\
\hline & & $\begin{array}{l}\text { Halal } \\
\text { Certification } \\
\text { Process }\end{array}$ & $\begin{array}{l}\text { Perception of } \\
\text { Halal } \\
\text { Certification } \\
\text { Costs }\end{array}$ & $\begin{array}{l}\text { Intention of } \\
\text { Creative } \\
\text { Economy } \\
\text { Actors } \\
\text { (MSMEs) }\end{array}$ \\
\hline \multirow[t]{3}{*}{$\begin{array}{l}\text { Halal Certification } \\
\text { Process }\end{array}$} & $\begin{array}{l}\text { Pearson } \\
\text { Correlation }\end{array}$ & 1 & $.719^{* *}$ & $.801^{* *}$ \\
\hline & Sig. (2-tailed) & & .000 & .000 \\
\hline & $\mathrm{N}$ & 100 & 100 & 100 \\
\hline \multirow[t]{3}{*}{$\begin{array}{l}\text { Perception of Halal } \\
\text { Certification Costs }\end{array}$} & $\begin{array}{l}\text { Pearson } \\
\text { Correlation } \\
\end{array}$ & $.719^{* *}$ & 1 & $.755^{* *}$ \\
\hline & Sig. (2-tailed) & .000 & & .000 \\
\hline & $\mathrm{N}$ & 100 & 100 & 100 \\
\hline \multirow{3}{*}{$\begin{array}{l}\text { Intention of Creative } \\
\text { Economy Actors } \\
\text { (MSMEs) }\end{array}$} & $\begin{array}{l}\text { Pearson } \\
\text { Correlation }\end{array}$ & $.801^{* *}$ & $.755^{* *}$ & 1 \\
\hline & Sig. (2-tailed) & .000 & .000 & \\
\hline & $\mathrm{N}$ & 100 & 100 & 100 \\
\hline
\end{tabular}

Result. Based on Table 7, the results of the Pearson correlation R4 calculation show that the value of the correlation coefficient between the halal certification process and the perception of the cost of halal certification with the intention of creative economy actors (MSMEs) from the calculation above $r_{-}(y .12)$ is 0.841 , this indicates very strong while $r$ table is 0.1966 for the two-tailed test with a sample size of 100. Because of the value of $r_{-}(y .12)>r_{-}($table ), then the result is significant. One of the efforts to make it easier for everyone who will make transactions and investments based on Sharia principles is the existence of sharia fintech financing (Santoso, Natanael, et al., 2021).

Based on Table 8 shows that there are four correlations between variables: I: Halal certification process and the intentions of creative economy business actors; II: Perception of halal certification costs and intentions of creative economy business actors; III: Certification process and cost perception of halal certification; IV: IV: The halal certification process, perception of halal certification costs and intentions of creative economy business actors are all significant. 
Table 8. Summary Result of Data Correlation Pearson Product Moment

\begin{tabular}{|c|c|c|}
\hline Correlation between Variables & Measurement Items & Result \\
\hline \multirow{3}{*}{$\begin{array}{l}\text { I: Halal certification process and } \\
\text { the intentions of creative economy } \\
\text { business actors }\end{array}$} & Correlation & 0.825 \\
\hline & Signification & 0.000 \\
\hline & Rtabel & 0.1654 \\
\hline \multirow{3}{*}{$\begin{array}{l}\text { II: Perception of halal certification } \\
\text { costs and intentions of creative } \\
\text { economy business actors. }\end{array}$} & Correlation & 0.755 \\
\hline & Significant & 0.000 \\
\hline & Rtabel & 0.1654 \\
\hline \multirow{3}{*}{$\begin{array}{l}\text { III: Certification process and cost } \\
\text { perception of halal certification }\end{array}$} & Correlation & 0.719 \\
\hline & Significant & 0.000 \\
\hline & Rtabel & 0.1654 \\
\hline \multirow{3}{*}{$\begin{array}{l}\text { IV: The halal certification process, } \\
\text { perception of halal certification } \\
\text { costs and intentions of creative } \\
\text { economy business actors }\end{array}$} & Correlation & 0,891 \\
\hline & Significant & 0.000 \\
\hline & Rtabel & 0.1654 \\
\hline
\end{tabular}

Source: Results of data processing

\section{Conclusion}

Based on the results and discussion to answer the research objectives, the following conclusions are obtained: The halal certification process (by assisting) strongly correlates with the intention of creative economy actors (MSMEs) for Food and Beverage and is significant, Perceptions of Halal Certification Costs (with subsidized Halal certification costs) strongly correlate with the intentions of Food and Beverage creative economy actors (MSMEs) and are significant, The Halal Certification Process strongly correlates with the Perception of Halal Certification Costs for Food and Beverage creative economy actors (MSMEs) and is significant, The halal certification process and the perception of the cost of halal certification with the intention of creative economy actors (MSMEs) for Food and Beverage show that it is very strong and significant.

While the recommendations from the results of this study are as follows: With the halal certification inspection process acceleration from 93 days to a maximum of 21 days by the Halal Guarantee Agency, it is easier for Food and Beverage Creative Economy actors (MSMEs) to get halal certification no longer wait too long to get halal certificates. Recommendations for policymakers regarding the convenience of halal certification for MSMEs (Ekraf actors) through simplifying the registration process and accelerating the issuance of MSME certification by BPJPH - Ministry of Religion without compromising existing standardization, namely (i) Certification time: the time for checking the certification process by the LPH (Examining Agency) Halal) no later than 21 days; (ii) requirements: specifically for micro-enterprises with products with a low level of risk and no risk, halal certification is obtained through a self-declaration/single permit. The application for halal certification for business actors in the regions can be made by visiting the Regional Offices of the Ministry of Religion in all provinces. Stakeholder synergy at the central and regional levels as well as related parties. The halal certification process and the perception of the cost of halal certification, both individually and collectively, correlate with food and beverage creative economy actors (MSMEs). In order to be integrated, holistic and comprehensive from KNEKS, the Ministry of Religion through BPJPH, the Ministry of Cooperatives and SMEs, the Ministry of Tourism and Creative Economy/Tourism and Creative Economy Agency, and the Ministry of Investment/BKPM, for the sake of accelerating the halal 
certification process, and facilitating the halal certification process as well as cost subsidies for micro and small businesses which are expected to have a significant impact on the sustainability of the intentions of business actors in obtaining halal certification, it is recommended that the Halal Food and Beverage Industry Development immediately be compiled and implemented by formulating a National Strategy for the Development of the Halal Food and Beverage Industry, Draft General Guidelines for the Halal Food and Beverage Industry Improving MSME Halal Quality, Development of Halal Food and Beverage Industrial Estates, Development of Halal One Stop Services (PTSP), Integration of Halal Licensing, and Digital Halal Business Incubation which are stakeholder synergies at both the central and regional levels area and related parties.

\section{References}

$\mathrm{Ab}$ Talib, M. S. (2017). Motivations and benefits of halal food safety certification. Journal of Islamic Marketing, 8(4), 605-624. https://doi.org/10.1108/JIMA-08-2015-0063

Adhiguna, E. T., Mahdi, M. F., Fauzan, M. N., Rabbani, Z. A., \& Santoso, S. (2021). Analisis Korelasi Implementasi Layanan Pesan Antar Berbasis Aplikasi Terhadap Penjualan Kafe Di Masa Pandemi Covid-19: Studi Kasus OCD Coffee Shop. Journal Industrial Manufacturing, 6(2), 115-122. https://doi.org/10.31000/jim.v6i2.4646

Agus, P. A. (2017). Kedudukan Sertifikasi Halal Dalam Sistem Hukum Nasional Sebagai Upaya Perlindungan Konsumen Dalam Hukum Islam. Amwaluna: Jurnal Ekonomi Dan Keuangan Syariah, 1(1), 150-165. https://doi.org/10.29313/amwaluna.v1i1.2172

Akim, A., Konety, N., Purnama, C., \& Korina, L. C. (2019). The Shifting of Halal Certification System in Indonesia: From Society-Centric To State-Centric. MIMBAR: Jurnal Sosial Dan Pembangunan, 35(1), 115-126. https://doi.org/10.29313/mimbar.v35i1.4223

Alika, V., Santoso, S., Nurmaliki, S., \& Anisa, N. (2021). Marketing Strategy Sharia Financial Institutions to Promote Sharia Fintech and Micro and Small Enterprises (MSES). Proceedings of the 1st MICOSS Mercu Buana International Conference on Social Sciences. EAI. https://doi.org/10.4108/eai.28-9-2020.2307373

Dumilah, D. R., Komarudin, M., Ubaidillah, R., Siagian, S., \& Santoso, S. (2021). Peran Ekonomi Kreatif dalam Meningkatkan Industri Pariwisata di Seaworld Ancol. Jurnal Master Pariwisata (JUMPA), 7(2), 558-583. https://doi.org/10.24843/JUMPA.2021.v07.i02.p10

Elasrag, H. (2016). Halal Industry: Key Challenges and Opportunities. SSRN Electronic Journal. https://doi.org/10.2139/ssrn.2735417

Faridah, H. D. (2019). Halal certification in Indonesia; history, development, and implementation. Journal of Halal Product and Research (JPHR), 2(2), 68-78.

Fatmawati, A. A., \& Santoso, S. (2020). Penguatan Rantai Nilai Pariwisata Sebagai Strategi Pengembangan Kawasan Kota Tua Jakarta Menjadi Kawasan Wisata Ramah Muslim. Jurnal Ilmiah Manajemen Dan Bisnis (JIMB), 6(3), 284-304.

Fauzan, H. A. (2020). Analisis Faktor Penghambat dan Pendorong Adopsi Sertifikasi Halal Bagi UKM Makanan dan Minuman di Indonesia Dengan Metode Dematel Based ANP. Universitas Indonesia.

Hasri, N. H., Taib, M. Z. M., \& Ahmad, S. S. (2016). Relevance of Regulatory Policies in Governing Adherence to Halal Concept in the Design of Food Premises in Malaysia. Procedia - Social and Behavioral Sciences, 222, 306314. https://doi.org/10.1016/j.sbspro.2016.05.168

Kemenparekraf/ Baparekraf RI. (2020). Siaran Pers : Kemenparekraf Dorong Penguatan Peran Ekonomi Syariah dalam Pengembangan Sektor Parekraf. Retrieved 4 August 2021, from Kemenparekraf/ Baparekraf RI website: https://kemenparekraf.go.id/berita/Siaran-Pers-:-Kemenparekraf-Dorong-Penguatan-PeranEkonomi-Syariah-dalam-Pengembangan-Sektor-Parekraf

Mohamad, N., \& Backhouse, C. (2014). A framework for the development of halal food products in Malaysia. Proceedings of the 2014 International Conference on Industrial Engineering and Operations Management, 10, 693702.

Pew Research Center. (2017). Muslims are projected to be the world's fastest-growing major religious group in the decades ahead. Retrieved 12 February 2021, from Pew Research Center website: https://www.pewresearch.org/fact-tank/2017/12/26/17-striking-findings-from-2017/

Prabowo, S., Abd Rahman, A., Ab Rahman, S., \& Samah, A. A. (2015). Revealing factors hindering halal certification in East Kalimantan Indonesia. Journal of Islamic Marketing, 6(2), 268-291. https://doi.org/10.1108/JIMA-052014-0040

Qomaro, G. W., Hammam, H., \& Nasik, K. (2019). Pemberdayaan Usaha Mikro Kecil dan Menengah Sektor Pangan dalam Meningkatkan Perekonomian Lokal Melalui Pendampingan Sertifikasi Halal di Kecamatan Tragah 
Bangkalan. Jurnal Ilmiah Pangabdhi, 5(2), 137-142. https://doi.org/10.21107/pangabdhi.v5i2.6116

Redata, L., Kezia, R., Solaiman, K. H., \& Santoso, S. (2021). Analisis Korelasi Pendampingan Komunitas Terhadap Inovasi Pelaku Ekonomi Kreatif Dan Pemenuhan Kebutuhan Konsumen: Studi Kasus Pada Komunitas Tangerang Berdaya Dan Pelaku Ekonomi Kreatif Kuliner. Business Management Journal, 17(1), 1-19.

Santoso, S. (2020). Optimizing Access to Financial Capital of Creative Economy for Startups Towards Global Competitiveness. Business Economic, Communication, and Social Sciences (BECOSS) Journal, 2(2), 181-189. https://doi.org/10.21512/becossjournal.v2i2.6246

Santoso, S., Hapsari, P. A., Difoasih, G., \& Prianto, S. E. (2021). Analysis of Public Interest In Online Tourism In The Middle of The Covid-19 Pandemic. JELAJAH: Journal of Tourism and Hospitality, 3(1), 1-11. https://doi.org/10.33830/jelajah.v3i1.1745

Santoso, S., Natanael, A., Griselda, A., Khoirunnisa, J., Simanjuntak, M. A., Bagus, R., \& Ana Fatmawati, A. (2021). Analisis Pengembangan Platform Ekspor Sub Sektor Kuliner Tinjauan Dari Model Sistem Inovasi. Distribusi - Journal of Management and Business, 9(1), 29-38. https://doi.org/10.29303/distribusi.v9i1.151

Sukoso. (2020). Pengembangan Ekonomi dan Keuangan Syariah Sektor Pariwisata dan Ekonomi Kreatif. Jakarta.

Syafrida, S. (2016). Sertifikat Halal Pada Produk Makanan Dan Minuman Memberi Perlindungan Dan Kepastian Hukum Hak-Hak Konsumen Muslim. ADIL: Jurnal Hukum, 7(2), 159-174.

Tadjuddin, T., \& Mayasari, N. (2019). Strategi Pengembangan UMKM Berbasis Ekonomi Kreatif Di Kota Palopo. Dinamis: Journal of Islamic Management and Bussiness, 2(1), 9-22.

Warto, W., \& Samsuri, S. (2020). Sertifikasi Halal dan Implikasinya Bagi Bisnis Produk Halal di Indonesia. Al Maal: Journal of Islamic Economics and Banking, 2(1), 98-112. https://doi.org/10.31000/almaal.v2i1.2803

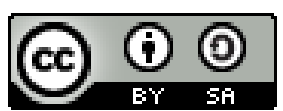

C 2021 by the authors. Submitted for possible open access publication under the terms and conditions of the Creative Commons Attribution (CC BY SA) license (https://creativecommons.org/licenses/by-sa/3.0/). 